\title{
Micronutrient synergy - a new tool in effective control of metastasis and other key mechanisms of cancer
}

\author{
A. Niedzwiecki • M. W. Roomi • T. Kalinovsky $・$ M. Rath
}

Published online: 18 August 2010

(C) The Author(s) 2010. This article is published with open access at Springerlink.com

\begin{abstract}
Consumption of a plant-based diet has been associated with prevention of the development and progression of cancer. We have developed strategies to inhibit cancer development and its spread by targeting common mechanisms used by all types of cancer cells that decrease stability and integrity of connective tissue. Strengthening of collagen and connective tissue can be achieved naturally through the synergistic effects of selected nutrients, such as lysine, proline, ascorbic acid and green tea extract (NM). This micronutrient mixture has exhibited a potent anticancer activity in vivo and in vitro in a few dozen cancer cell lines. Its anti-cancer effects include inhibition of metastasis, tumor growth, matrix metalloproteinase (MMP) secretion, invasion, angiogenesis, and cell growth as well as induction of apoptosis. Many cancers are often diagnosed at later stages, when metastasis has occurred, which standard treatment has been unable to control. Our studies on NM effects on hepatic and pulmonary metastasis demonstrated profound, significant suppression of metastasis in a murine model. Evaluation of effects of NM on xenografts in murine models demonstrated significant reduction in tumor size and tumor burden in all human cancer cell lines tested. In vitro studies demonstrated that $\mathrm{NM}$ was very effective in inhibition of cell proliferation (by MTT assay), MMP secretion (by gelatinase zymography), cell invasion (through Matrigel), cell migration (by scratch test), induction of apoptosis (by live green caspase) and induction of pro-apoptotic genes in many diverse cancer cell lines.
\end{abstract}

A. Niedzwiecki $(\bowtie) \cdot$ M. W. Roomi $\cdot$ T. Kalinovsky $\cdot$ M. Rath Dr. Rath Research Institute,

1260 Memorex Drive,

Santa Clara, CA 95050, USA

e-mail: author@drrath.com
Furthermore, in vivo and in vitro studies of effects of individual micronutrients compared to their specific combination demonstrated synergistic effects resulting in improved anticancer potency.

Keywords Micronutrients · Synergy · In vivo In vitro . Metastasis $\cdot$ Tumor growth

\section{Introduction}

In 2009 , there were 562,340 cancer deaths overall, including 159,390 deaths from lung cancer; 49,920 from cancer of the colon/rectum; 40,610 from female breast cancer; 35,240 deaths from cancers of the pancreas; and 27,360 from prostate cancer. Despite extensive use of conventional therapies, cancers such as liver, intrahepatic bile duct, esophageal, and pancreatic continue to increase [1]. Furthermore, cancers are often diagnosed at a later stage, when metastasis has occurred, which standard treatment has been unable to control. Standard cancer treatments, which have been largely unsuccessful, generally involve a combination of surgery, multiple chemotherapeutic agents, and ionizing radiation. Evaluation of clinical trials conducted between 1990 and 2004 on 22 types of cancer showed that chemotherapy could increase the chance of 5 -year survival by merely $2.1 \%$ [2]. At the same time, it is not effective in treating melanoma, uterine, prostate, and kidney cancers. The main reasons behind disappointing outcomes of chemotherapy are its severe toxicity, immune involvement, and genotoxicity, giving rise to new cancers, as well as development of drug resistance by cancer cells. In addition to being unsuccessful in treating cancer, standard cancer treatments are associated with high costs, which have led to the immense increased cost of healthcare. 
Thus, there is a need for defining new biological targets and non-toxic solutions.

\subsection{Natural approaches in cancer therapy}

Numerous studies indicate that consumption of a plantbased diet has preventive effects on cancer development and its progression $[3,4]$. Many natural compounds such as herbal extracts, vitamins (i.e., vitamin C) and micronutrients have been used in cancer treatment; however, the application of most of natural approaches have been largely based on traditional use and personal experiences with no clear understanding of their cellular targets and mechanisms of action. Research in the area of natural health has been limited and progress slow due to lack of funding for investigations of natural compounds, as they are not patentable and thus would result in low profits.

Since $90 \%$ of cancer deaths occur secondary to metastasis, any successful anti-cancer treatment has to target this stage of cancer development. Dr. Rath and his colleagues have paved a new direction in the therapeutic use of micronutrients to control cancer growth and metastasis by targeting common pathomechanisms involved in growth and invasion for all types of cancer. A major breakthrough by Dr Rath proposed that collagen stability is the most effective and universal approach to controlling cancer [5]. In this aspect, controlling matrix proteolytic degradation and enhancing extracellular matrix (ECM) structure and its integrity are key steps towards curbing cancer invasiveness and tumor growth. Studies by Almholt et al. [6] have demonstrated limited metastasis in serine (u-PA) deficient mouse model. Also highly metastatic cancer cells secrete higher amounts of matrix metalloproteinases (MMPs) than do poorly metastatic cells, demonstrating that the invasive and metastatic abilities of these cancer cells correlate with an ability of these enzymes to degrade basement membranes [7,8]. Since this process is involved not only in metastasis, but also in angiogenesis and tumor growth, control of proteolytic activity of ECM provides an opportunity to modulate key common aspects of malignancy.

A major structural protein for ECM and basement membrane is Type IV collagen. Therefore, type IV collagenases MMP-2 (72-kd gelatinase A) and MMP-9 (92-kd gelatinase $\mathrm{B}$ ) have been the focus of research, especially since MMP-2 and MMP-9 expression is associated with cancer cell invasion and is elevated in a variety of malignancies $[9,10]$. A significant association has been reported between tumor aggression and increased levels of MMP-2 and MMP-9 in many experimental and clinical studies [11, 12]. The activity of MMPs on the degradation of the ECM plays a critical role in the formation of tumors and metastasis and has been found to correlate with the aggressiveness of tumor growth and invasiveness of the cancer $[8,12]$.
1.2 Novel approach to cancer through nutrient synergy

Rath and Pauling [5] suggested targeting plasmin-mediated connective tissue degradation as a universal approach to controlling common pathomechanisms of cancer. They proposed the use of nutritional components, such as vitamin $\mathrm{C}$ and lysine and lysine analogs. Lysine interferes with the activation of plasminogen into plasmin by tissue plasminogen activator by binding to plasminogen active sites, thereby affecting the plasmin-induced MMP activation cascade [5]. Our subsequent studies confirmed the approach described by Rath and Pauling [5] and resulted in identifying a novel formulation composed of lysine, ascorbic acid, proline and green tea extract and other micronutrients (NM) which has shown significant anticancer activity against a large number $(\sim 40)$ of cancer cell lines, blocking cancer growth, tissue invasion, and MMP expression both in vitro and in vivo [13, 14]. Furthermore, NM demonstrated significant antiangiogenic activity utilizing the chorioallantoic membrane assay in chick embryos and bFGF-induced vessel growth in C57BL/6 J female mice in the mouse Matrigel plug assay [15]. In addition, in vitro, NM decreased the expression of pro-angiogenic factors of VEGF, angiopoietin-2, bFGF, PDGD, and TDG $\beta-1$ by U2OS cells [15].

\subsection{Defining active compounds}

The NM was formulated by selecting nutrients that act on critical physiological targets in cancer progression and metastasis. The anticancer effects of the individual constituents of the NM have been reported in both clinical and experimental studies. Adequate supplies of ascorbic acid and the amino acids lysine and proline are essential for optimal ECM formation and structure as these nutrients insure proper synthesis and hydroxylation of collagen fibers. Manganese and copper are also essential for collagen formation. Lysine contributes to ECM stability as a natural inhibitor of plasmin-induced proteolysis $[5,16]$. Green tea extract has been shown to control cancer cell growth, metastasis, angiogenesis, and other aspects of cancer progression [17-23].

$\mathrm{N}$-acetyl cysteine and selenium have been observed to inhibit MMP-9 and invasive activities of tumor cells, as well as migration of endothelial cells through ECM [2426]. Ascorbic acid has been reported to exert cytotoxic and antimetastatic actions on malignant cell lines [27-29]; in addition, low levels of ascorbic acid have been reported in cancer patients [30,31]. Arginine is a precursor of nitric oxide (NO); any deficiency of arginine can limit the production of NO, which has been shown to predominantly act as an inducer of apoptosis, as in breast cancer cells [32]. 
Combining these micronutrients expands metabolic targets maximizing the biological impact with lower doses of components by nutrient synergy. Furthermore, effective lower doses of components using nutrient synergy also assure overcoming absorption barriers characteristic for high vitamin doses.

\section{Micronutrient synergy enhances anticancer effects of micronutrients}

The synergistic anticancer effect of micronutrients is exemplified in the study of Kale et al. [33] on the treatment of N-methyl-N-nitrosourea (MNU)-induced mammary tumors in Wistar rats. Different micronutrient treatment regimens were provided after rats had developed palpable tumors to correspond to intervention treatment approaches in clinical settings. The combination of micronutrients NM (which contains $30 \mathrm{mg}$ green tea extract (GTE)) showed improvement over $30 \mathrm{mg}$ GTE alone, and addition of quercetin and other micronutrients further enhanced the antitumor effect. Tumors in the group of rats treated with $\mathrm{NM}+\mathrm{GTE}+$ quercetin not only were smaller than those in other groups, but also the number of carcinomas was reduced to six compared to 24 in the positive control and 10-14 in the other groups, as shown in Table 1. These results demonstrate the superior treatment of tumors by the cooperative effect of micronutrient synergy. In a previous study, the NM was shown to prevent incidence, tumor weight and tumor burden in female Sprague-Dawley rats $(n=20)$ that received a single intraperitoneal (IP) dose $(50 \mathrm{mg} / \mathrm{kg})$ of MNU. Two weeks after MNU injection, the animals were divided into two groups and fed either Purina chow or with NM (0.5\%)supplemented Purina chow. After 24 weeks, the group of rats receiving the NM diet showed a reduction in tumor incidence by $68.4 \%$, mean tumor weight by $78 \%$ ( $p=$ $0.0001)$, and tumor burden $60.5 \%(p=0.0001)$ compared to the control group of rats. In addition, the rats in the control group developed large adenocarcinomas, including increased mitotic index and prominent angiogenesis, while those in the NM-supplemented group developed small adenomas with low mitotic index [34].

Another study, an in vitro study, evaluated the potency of the components EGCG and GTE independently compared to their combination with other micronutrients $(\mathrm{NM})$ on modulation of MMP-2 and MMP-9 secretion patterns in four cancer cell lines expressing MMP-2, MMP-9, or both. Investigation of the comparative effects of GTE and EGCG to $\mathrm{NM}$ at equivalent amounts found in 50, 100, 250, 500, and $1,000 \mu \mathrm{g} / \mathrm{mL}$ concentrations of $\mathrm{NM}$ in uniduced and PMA-treated cancer cell lines (fibrosarcoma, hepatocellular carcinoma, glioblastoma, and leimyosarcoma) demonstrated the superior inhibitory action of NM over GTE and EGCG on secretion of MMPs. The superior potency of NM over GTE and EGCG can be understood from the more comprehensive treatment offered by the combination of nutrients in NM over individual components of NM since MMP-2 and MMP-9 are mediated by differential pathways. NM components LPA (a mixture of lysine, proline, and ascorbic acid), N-acetyl cysteine, and selenium independently had no effect on MMP-2 and MMP-9 expression by these cancer cell lines. Thus NM, which comprises a mixture of all these components, demonstrated superior inhibitory activity on MMP secretion from a synergistic, rather than from an additive effect. This study is significant as it suggests the importance of nutrients working in cooperation to more effectively treat complex biochemical pathways. Figure 1 provides the zymograms and densitometric analyses of MMP-2 and -9 secretion by PMAinduced fibrosarcoma HT-1080 cells treated with the different micronutrient regimens,

\subsection{Nutrient synergy controls metastasis}

Our experimental results have confirmed the effectiveness of the micronutrient mixture in controlling metastasis and invasive parameters.

Table 1 Comparative effects of micronutrient regimens in MNU-induced mammary tumors

\begin{tabular}{lllll}
\hline Treatment & $\begin{array}{l}\text { Number of } \\
\text { Tumors/rat }\end{array}$ & $\begin{array}{l}\text { Size of } \\
\text { tumors/rat } \\
(\mathrm{cc})\end{array}$ & $\begin{array}{l}\text { Weight of } \\
\text { tumors/rat (g) }\end{array}$ & $\begin{array}{l}\text { Number of carcinomas (C) } \\
\text { and benign tumors (BT) }\end{array}$ \\
\hline $\begin{array}{l}\text { No treatment (positive control) } \\
\text { Green Tea Extract (30 mg) }\end{array}$ & $4.0 \pm 0.89$ & $10.36 \pm 6.00$ & $5.71 \pm 2.39$ & $24 \mathrm{C}, 1 \mathrm{BT}$ \\
$\mathrm{NM} 130 \mathrm{mg}($ containing $30 \mathrm{mg}$ GTE) & $2.0 \pm 1.09$ & $7.27 \pm 6.32$ & $5.33 \pm 4.72$ & $14 \mathrm{C}, 5 \mathrm{BT}$ \\
$\mathrm{NM} 130 \mathrm{mg}+\mathrm{N}(202 \mathrm{mg}$ ascorbic acid, $155 \mathrm{mg}$ lysine- & $1.4 \pm 0.81^{*}$ & $3.39 \pm 2.42$ & $1.71 \pm 1.34$ & $10 \mathrm{C}, 15 \mathrm{BT}$ \\
$\mathrm{HCl}, 12 \mathrm{mg}$ proline, $36 \mathrm{mg}$ citrus flavonoids) & $1.4 \pm 0.95^{*}$ & $3.52 \pm 2.94$ & $1.59 \pm 1.25$ & $12 \mathrm{C}, 10 \mathrm{BT}$ \\
$\mathrm{N}+$ quercetin $0.3 \mathrm{mg}$ & $1.0 \pm 0.53^{\mathrm{a}}$ & $2.69 \pm 1.76^{\mathrm{a}}$ & $1.35 \pm 0.93^{\mathrm{a}}$ & $6 \mathrm{C}, 15 \mathrm{BT}$ \\
$\mathrm{NM}+\mathrm{N}+$ quercetin $0.3 \mathrm{mg}$ & & $4.13 \pm 2.74$ & $1.70 \pm 1.11$ & $14 \mathrm{C}, 10 \mathrm{BT}$ \\
\hline
\end{tabular}

${ }^{\text {a }}$ Significantly differed from positive control group values $(p<0.05)$ by Student's $t$ test 


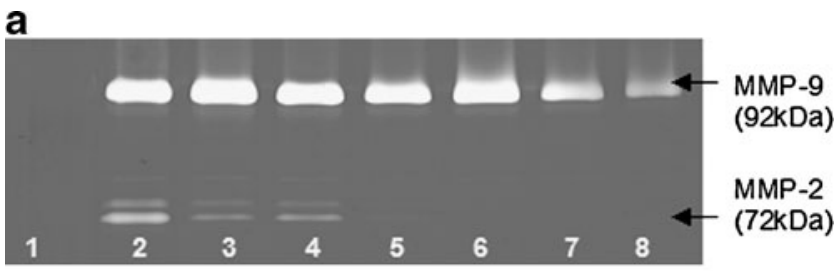

b
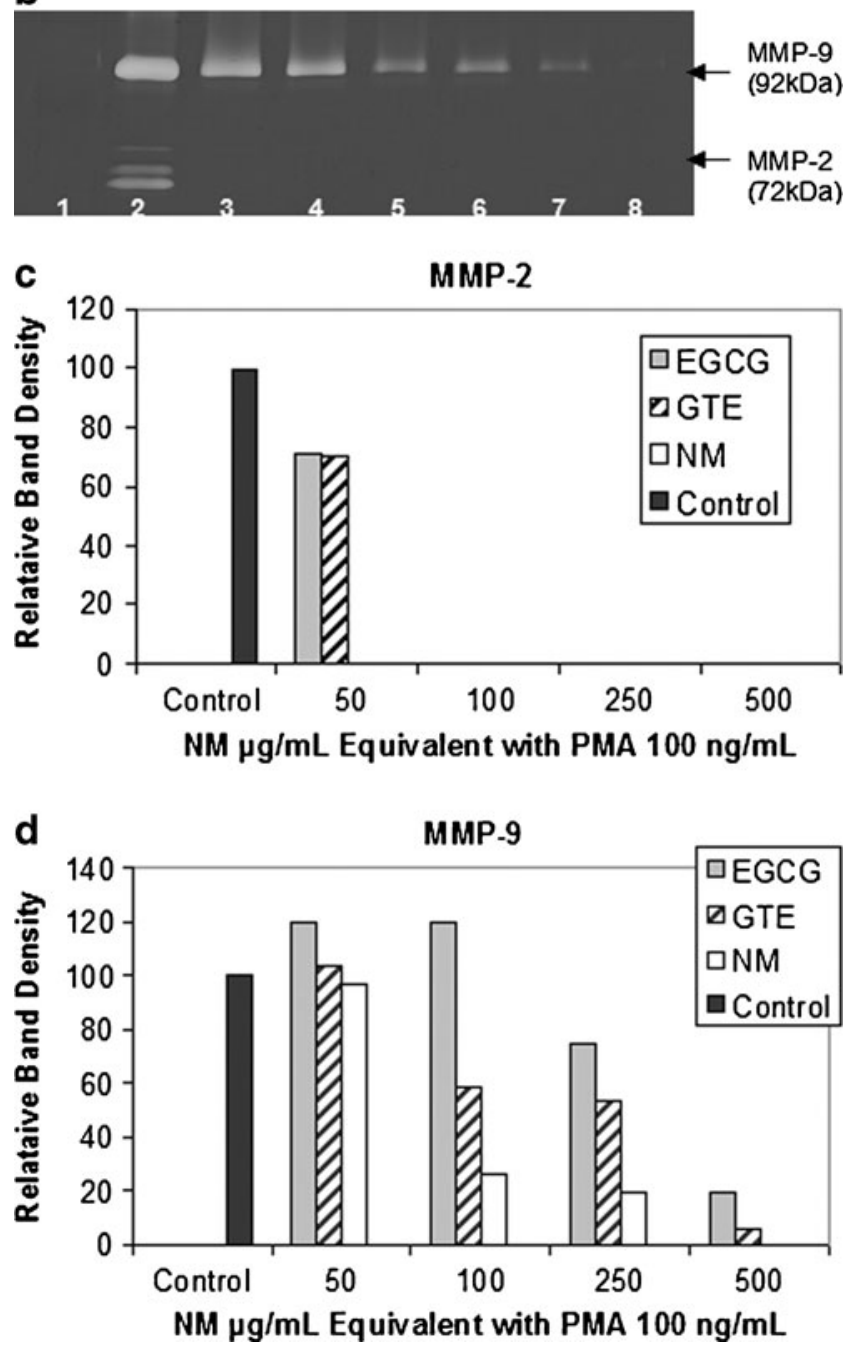

Fig. 1 Comparative effects of EGCG, GTE, and NM on MMP-2 and MMP-9 expression of PMA-treated human fibrosarcoma HT-1080 cells. a-b Gelatinase zymograms of HT-1080 cells showing dosedependent inhibition of MMP-2 and MMP-9 expression. NM was the most potent followed by GTE and EGCG. a 1 markers, 2 control, 3-5 $50 \mu \mathrm{g} / \mathrm{mL}$ NM EQ of EGCG, GTE, and NM, respectively; 6$8100 \mu \mathrm{g} / \mathrm{mL}$ NM EQ of EGCG, GTE, and NM, respectively. b 1 markers, 2 control, 3-5 $250 \mu \mathrm{g} / \mathrm{mL}$ NM EQ of EGCG, GTE, and NM, respectively; 6-8 $500 \mu \mathrm{g} / \mathrm{mL} \mathrm{NM}$ EQ of EGCG, GTE, and NM, respectively. c-d Quantitative densitometry showing comparative effects of NM, GTE and EGCG on HT-1080 cell (c) MMP-2 and (d) MMP-9 expression

\subsubsection{Pulmonary metastasis}

Pulmonary metastasis was studied in 6-7 week-old female C57BL/6 mice, which were divided into six groups of six mice each [35]. Groups 1-4 were injected via tail vein with B16FO melanoma cells $\left(5 \times 10^{4} /\right.$ mouse $)$, group 5 was injected in the tail vein with the same number of $\mathrm{B} 16 \mathrm{FO}$ melanoma cells pretreated with NM $(500 \mu \mathrm{g} / \mathrm{mL}$ for $18 \mathrm{~h})$, and group 6 (untreated control) was injected with the vehicle saline. Subsequently, the mice were placed on the following diet regimens and administration routes for NM: groups 1 and 5 were fed Purina mouse chow, the control diet; group 2 mice were given NM IP ( $4 \mathrm{mg} /$ mouse, $3 \times /$ week $\times 2$ weeks) and fed the control diet; group 4 was give NM intravenously (IV; $4 \mathrm{mg} /$ mouse, $3 \times /$ week $\times 2$ weeks and fed the control diet). Group 6 mice were fed the control diet. Two weeks later, the mice were sacrificed, and their lungs were excised, weighed, and processed for histopathologic examination. The weights of the lungs were obtained and the number of metastases and number of cells in each metastatic lesion were counted. Lungs isolated from mice injected with $5 \times 10^{4}$ B16FO cells and fed NM 0.5\% diet (group 2) had fewer metastatic colonies (by $63 \%, p<0.0001$ ) than did the lungs of mice fed the control diet (group 1), as shown in Figs. 2, 3, and 4. Pulmonary colonization was inhibited by $86 \%(p<$ 0.0001 ) in mice receiving NM by IP and IV injections (groups 3 and 4). The lungs from mice injected with viable melanoma cells pretreated with NM (group 5) were free from any metastasis. Thus, exposing melanoma cells to NM inhibited their ability to metastasize without the need for diet supplementation, suggesting profound changes on a cellular level.

\subsubsection{Hepatic metastasis}

Highly metastatic melanoma is resistant to existing therapies. Hepatic metastasis was studied in athymic nude mice,

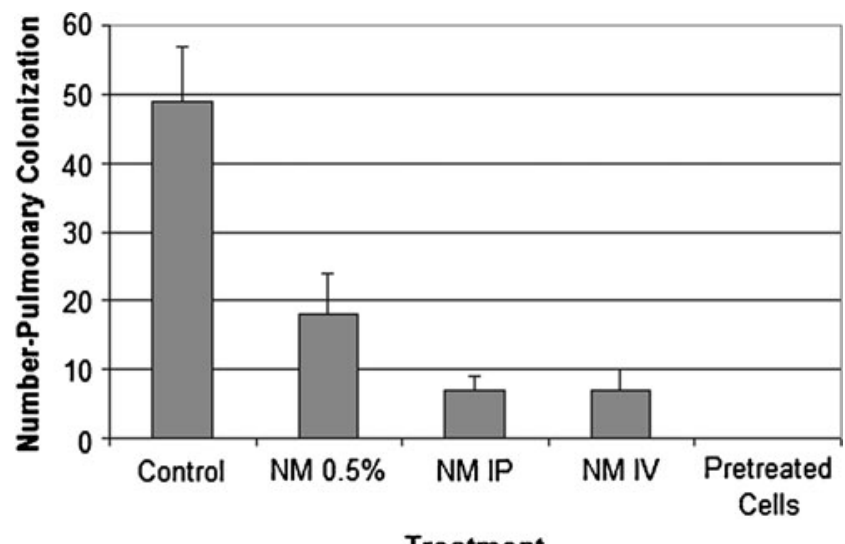

Fig. 2 Effect of NM on pulmonary colonization of B16FO cells $(5 \times$ $10^{4}$ ) injected in C57BL/6 mice 


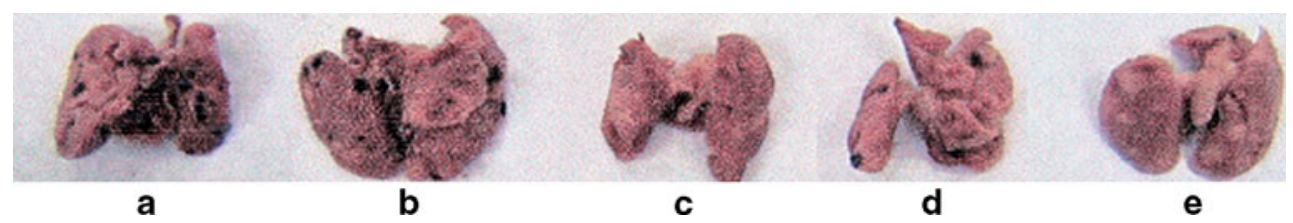

Fig. 3 Effect of NM on lungs of $\mathrm{C} 57 \mathrm{~B} 1 / 6$ mice injected with $\mathrm{B} 16 \mathrm{FO}$ cells $\left(5 \times 10^{4}\right)$ : gross lung photographs. Left to right: group 1 control diet, group 2 NM diet, group 3 NM IP, group 4 NM IV, group 5 NM pretreated cells

10-12 weeks old, which received $10^{6}$ B16FO melanoma cells by injection into the spleen and divided into two groups [36]. The control group of mice received Purina mouse chow and the NM group received the regular diet supplemented with NM $0.5 \%$. After 2 weeks, animals were sacrificed and spleens, livers, kidneys, and lungs were excised from all animals, examined, weighed, and processed for histology. The control mice developed large black spleens and livers indicating growth in the spleen and metastasis to the liver. However, the mice supplemented with NM not only showed less tumor growth in the spleen as the Control mice, but also drastically reduced metastasis to the liver (Figs. 5a-d). Intrasplenic tumor growth (mean spleen weight) was reduced significantly (by $64 \%, p=$ 0.001) in the NM-supplemented group compared to the control group (Table 2). Hepatic metastasis in NMsupplemented mice was reduced by $55 \% \quad(p=0.006)$ compared to the control group, based on mean liver weights
Fig. 4 Effect of NM on pulmonary colonization of B16-FO cells $\left(5 \times 10^{4}\right)$ injected in C57BL/6 mice: histology. a Control diet $40 \times$, b control diet $200 \times$, c NM $0.5 \%$ diet $40 \times$, d NM 4 mg IP 200×, e NMpretreated cells $40 \times$, f untreated control $200 \times$
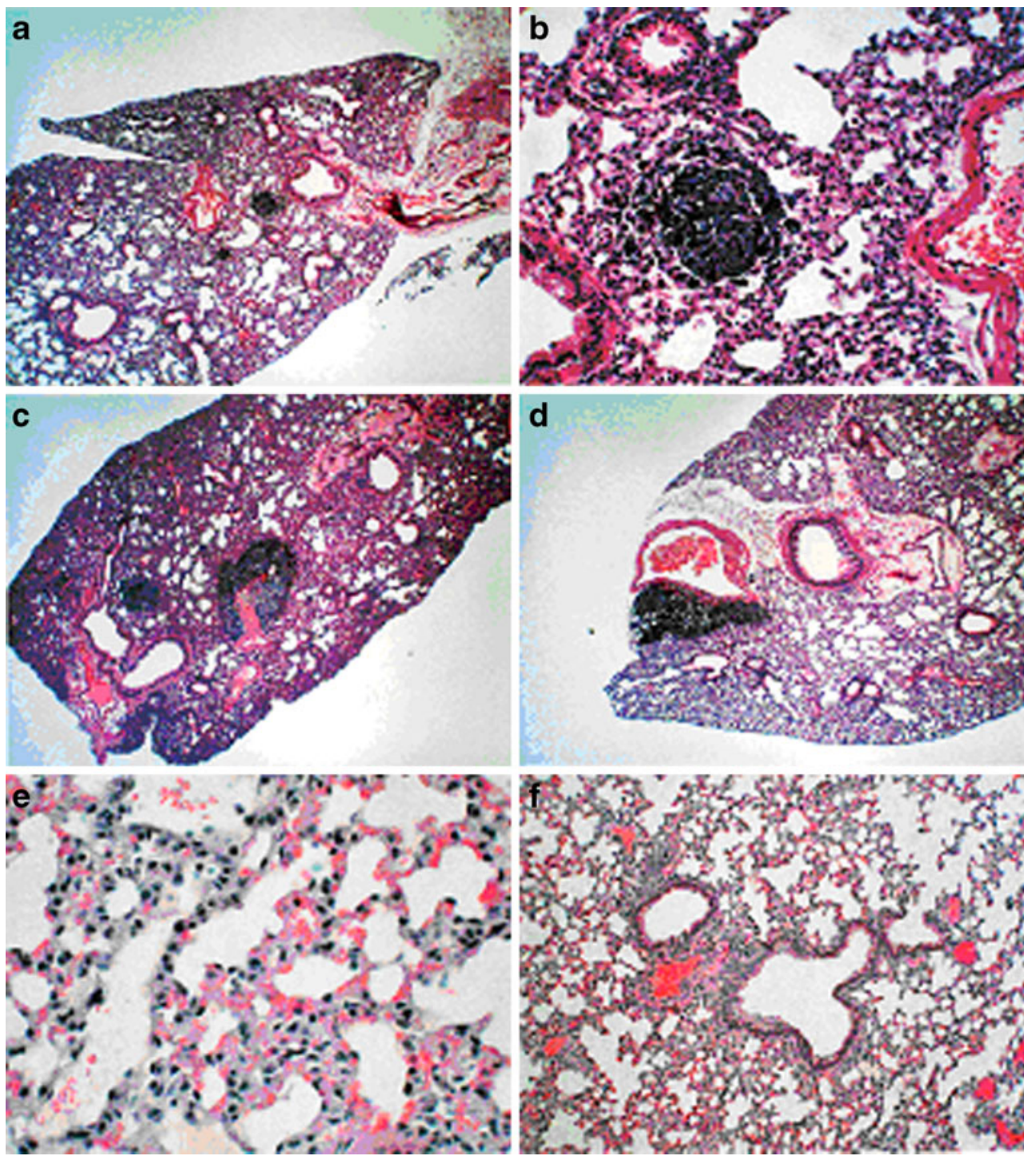


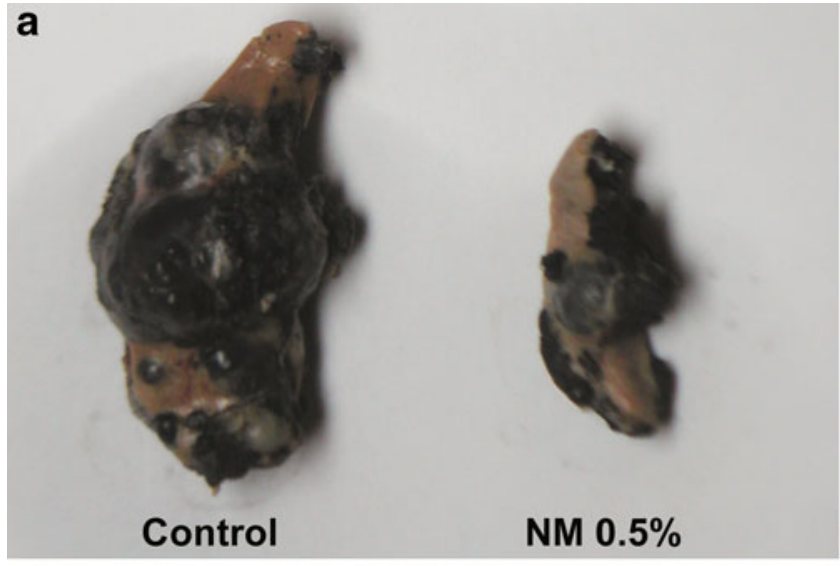

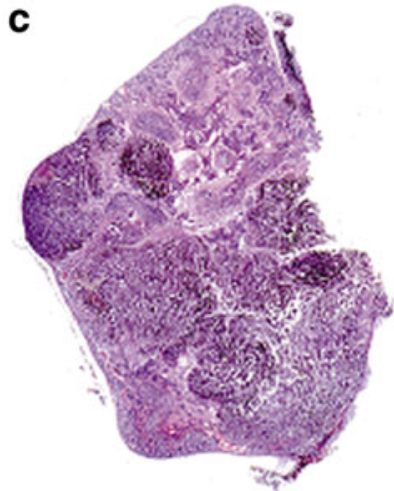

Control

d

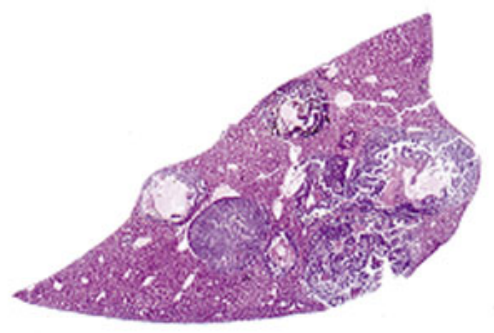

Control

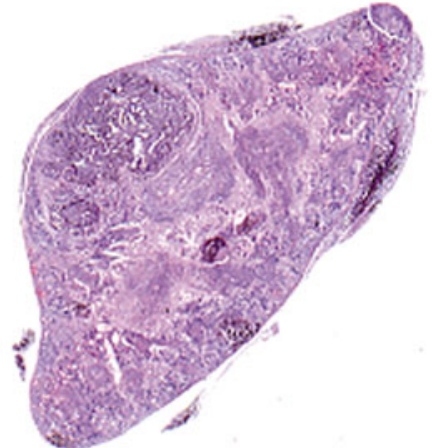

NM $0.5 \%$

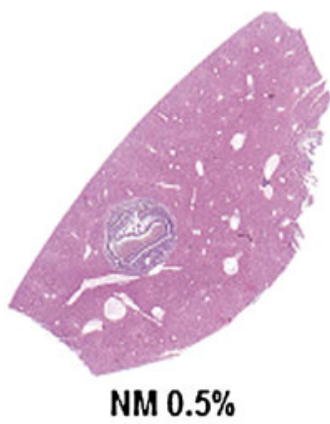

Control

NM $0.5 \%$

Fig. 5 Representative a spleens, $\mathbf{b}$ livers, and $\mathbf{c}$ spleen sections and $\mathbf{d}$ liver sections from Control and NM-supplemented nude mice receiving intrasplenic injection of $10^{6} \mathrm{~B} 16 \mathrm{FO}$ cells

of the groups. In all groups, no metastasis to the kidneys and lungs was evident. In conclusion, these results suggest that NM has potential in suppression of tumor metastasis. In the liver sections of control mice, multiple, nodular, metastatic lesions replaced most of the examined liver. In contrast, the liver sections of NM-supplemented mice showed only two to five small metastases. We also studied the effect of NM dietary treatment on the survival time of C57BL/6 mice after receiving an injection of $10^{6} \mathrm{~B} 16 \mathrm{FO}$ cells IP [37]. Group $1(n=6)$ received no B16FO cells and regular Purina mouse chow, group $2(n=6), 10^{6} \mathrm{~B} 16 \mathrm{FO}$ cells IP and regular Purina mouse chow, group 3, $10^{6}$ B16FO cells IP and 0.5\% NM-supplemented Purina mouse chow, and group $4,10^{6} \mathrm{~B} 16 \mathrm{FO}$ cells IP, regular Purina mouse chow and $2 \mathrm{mg}$ NM injected $3 \times /$ week. The number of animals surviving was counted daily. The NM dietary treatment group (3) resulted in increased survival over the control diet group (2) mice, as shown in the Kaplan-Meier survival curve (Fig. 6). The longest survival time (22 days) for groups was reached by a mouse in group 3, whose survival was 5 days longer than that of group 2 mice. Group 3 mice exhibited a mean increase in survival time of 1.4 days over that of group 2 mice, which showed a mean survival time of 15.2 days versus 16.7 days for group 3 mice. Group 4 mice had a mean survival time of 15.2 days.

2.2 Nutrient synergy modulates various parameters critical to metastasis: secretion of MMPS, uPA, tissue inhibitors of metalloproteinases (TIMPs), cancer cell migration, and Matrigel invasion

Proteases play a key role in tumor cell invasion and metastasis due to their ability to digest basement membrane and ECM components. Two families of proteases: u-PA and MMPs-2
Table 2 Effect of $10^{6} \mathrm{~B} 16 \mathrm{FO}$ cells administered into spleens of male nude mice on mean organ weights of groups control group, regular diet post injection; NM group, NM $0.5 \%$ supplemented diet post injection

\begin{tabular}{lcc}
\hline Organs & Control group $(n=5)$ mean organ weight $(\mathrm{g})$ & NM group $(n=5)$ mean organ weight $(\mathrm{g})$ \\
\hline Spleen & $2.76 \pm 0.77$ & $0.989 \pm 0.151$ \\
Liver & $4.59 \pm 1.5$ & $2.08 \pm 0.185$ \\
Kidney & $0.602 \pm 0.006$ & $0.599 \pm 0.009$ \\
Lung & $0.18 \pm 0.057$ & $0.197 \pm 0.003$ \\
\hline
\end{tabular}




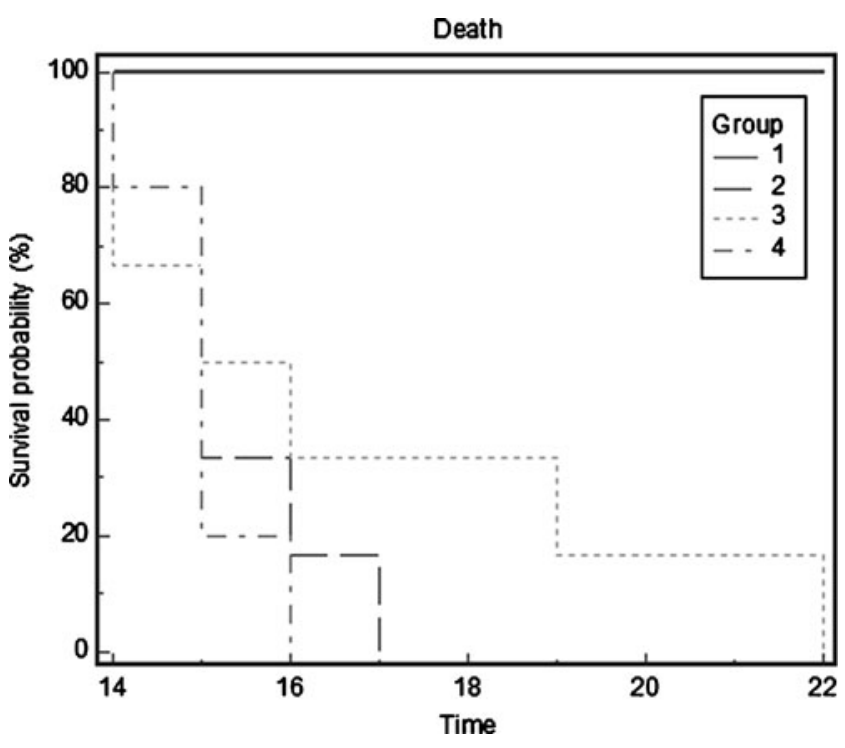

Fig. 6 Effect of NM treatment on survival of C57BL/6 mice receiving B16FO melanoma cells IP (Kaplan-Meier survival curve)

and -9 are necessary for invasive and metastatic potential. Strong clinical and experimental evidence shows that elevated levels of u-PA and MMPs are associated with tumor growth, cancer progression, metastasis, and shortened survival in patients. MMP activities are regulated by specific TIMPs. U$\mathrm{Pa}$ and MMPS are expressed in many tumor cell lines.

a

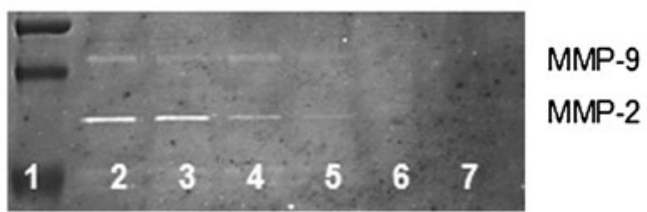

b

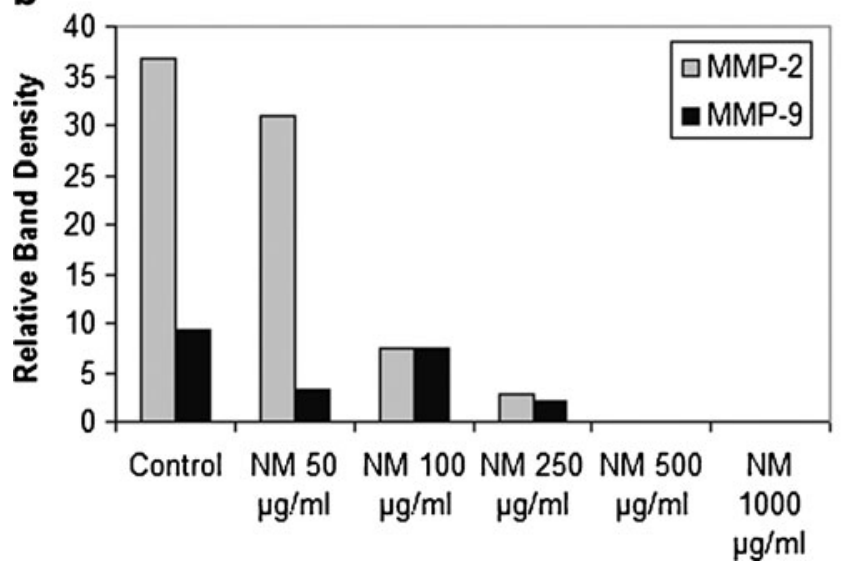

Fig. 7 Effect of NM on uninduced prostate PC-3 cell MMP-2 and MMP-9 secretion (a) and on PMA (100 ng/ml)-treated PC-3 cell MMP-2 and MMP-9 secretion (c). 1 markers, 2 control, 3-7 NM 10,
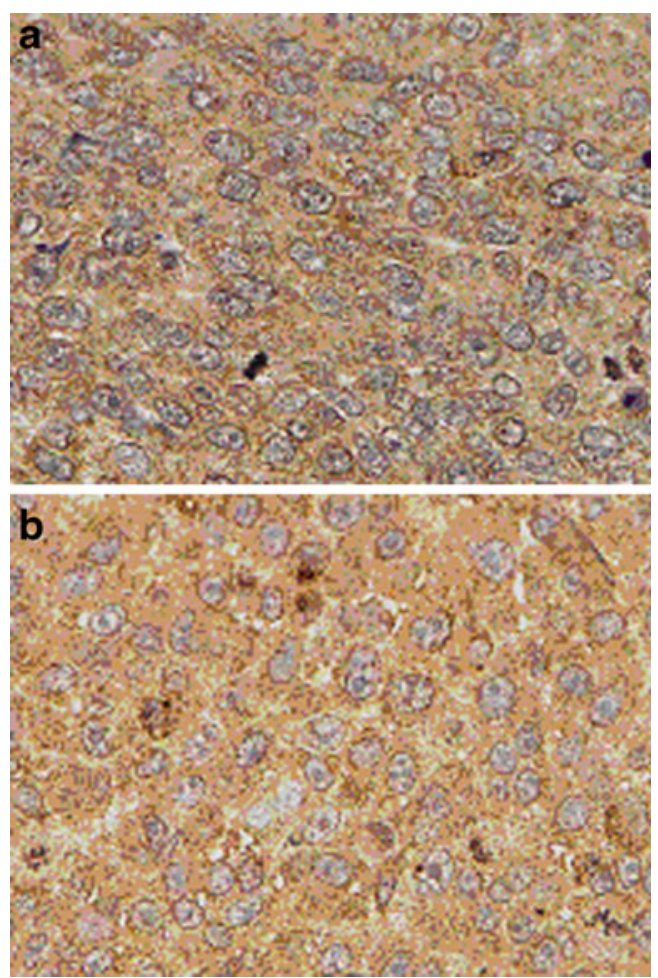

Fig. 8 Immunohistochemistry of human fibrosarcoma HT-1080 xenografts in male nude mice showing MMP9 levels a control group, b NM supplemented group

C

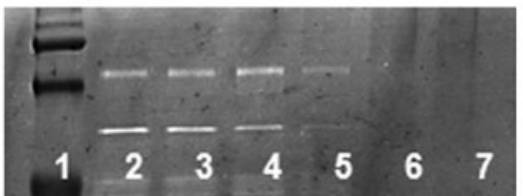

MMP-9

MMP-2

d

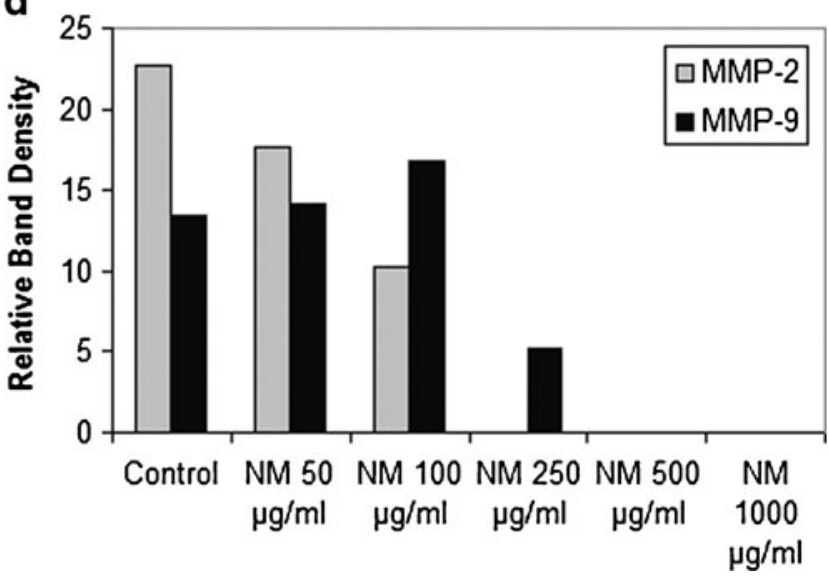

$50,100,500,1,000 \mu \mathrm{g} / \mathrm{ml}$. Densitometric analyses of uninduced PC-3 cells (b) and PMA-treated PC-3 cells (d) 


\subsubsection{Nutrient synergy inhibits MMP secretion}

Using gelatinase zymography, we evaluated MMP-2 and MMP-9 secretion in many cancer cell lines, some expressing only MMP-2 or MMP-9 and some expressing both. Gelatinase zymography was performed in $10 \%$ Novex PreCast sodium dodecyl sulfate (SDS) Polyacrylamide Gel (Invitrogen Corporation) in the presence of $0.1 \%$ gelatin under non-reducing conditions. Culture media $(20 \mu \mathrm{L})$ were mixed with sample buffer and loaded for SDSpolyacrylamide gel electrophoresis (PAGE) with Tris glycine SDS buffer, as suggested by the manufacturer (Novex). Samples were not boiled before electrophoresis. Following
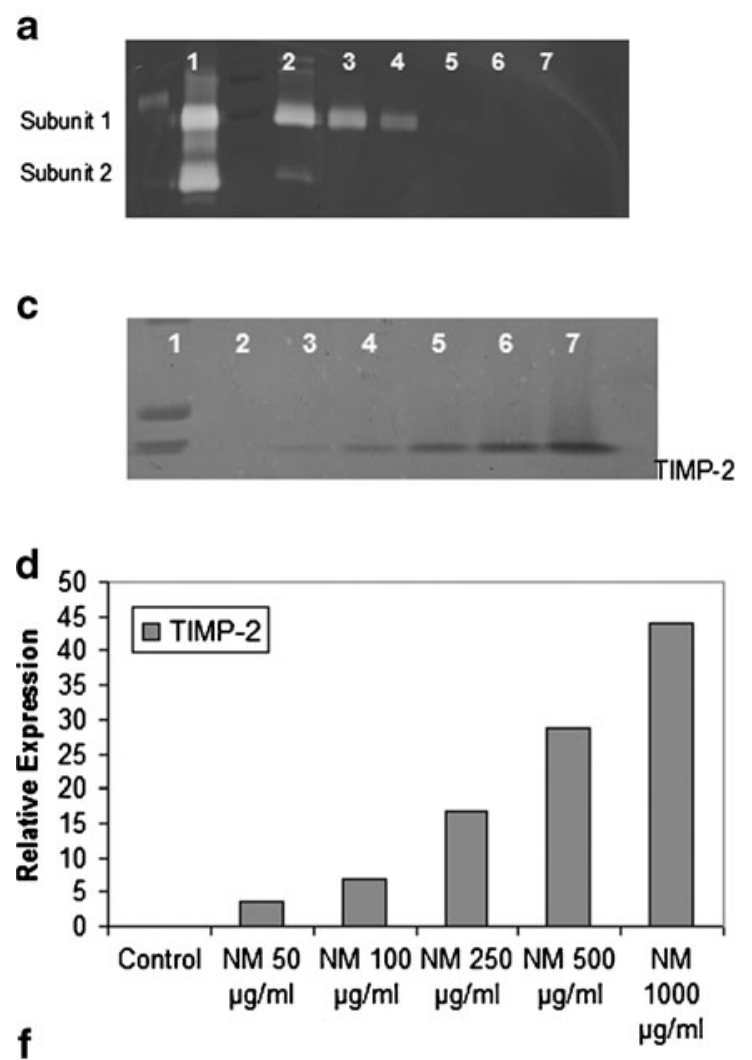

f

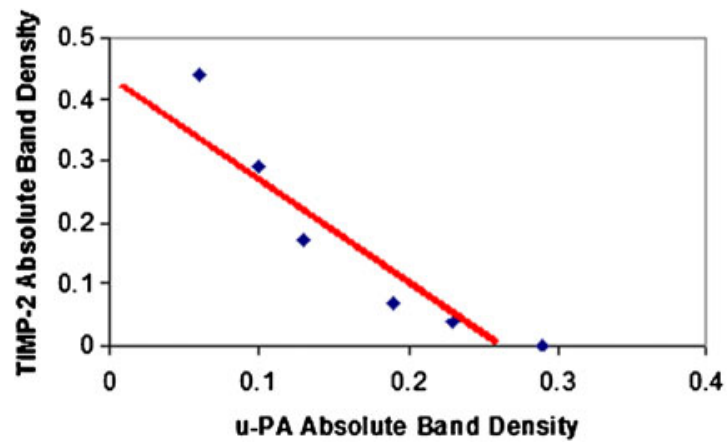

Fig. 9 Effect of NM on prostate PC-3 cell u-PA secretion (a) and on TIMPs secretion (c). 1 Markers, 2 control, 3-7 NM 10, 50, 100, 500, $1,000 \mu \mathrm{g} / \mathrm{ml}$. Densitometric analyses of PC-3 u-PA secretion (b) and electrophoresis, the gels were washed twice in $2.5 \%$ Triton $\mathrm{X}$ 100 for $30 \mathrm{~min}$ at room temperature to remove SDS. The gels were then incubated at $37^{\circ} \mathrm{C}$ overnight in substrate buffer containing $50 \mathrm{mM}$ Tris- $\mathrm{HCl}$ and $10 \mathrm{mM} \mathrm{CaCl} 2$ at $\mathrm{pH} 8.0$ and stained with $0.5 \%$ Coomassie Blue R250 in 50\% methanol and $10 \%$ glacial acetic acid for $30 \mathrm{~min}$ and destained. Upon renaturation of the enzyme, the gelatinases digested the gelatin in the gel, producing clear bands against an intensely stained background. Protein standards were run concurrently and approximate molecular weights were determined by plotting the relative mobilities of known proteins. Gelatinase zymograms were scanned using CanoScan 9950F scanner at 300 dpi.

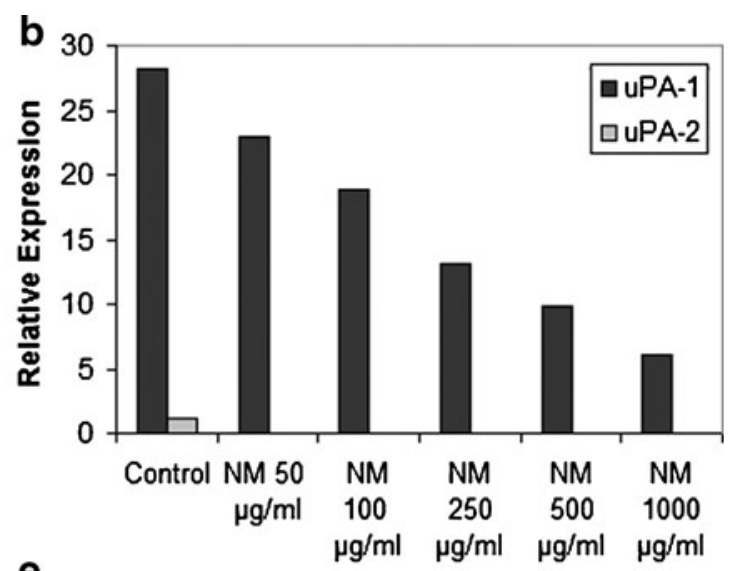

e
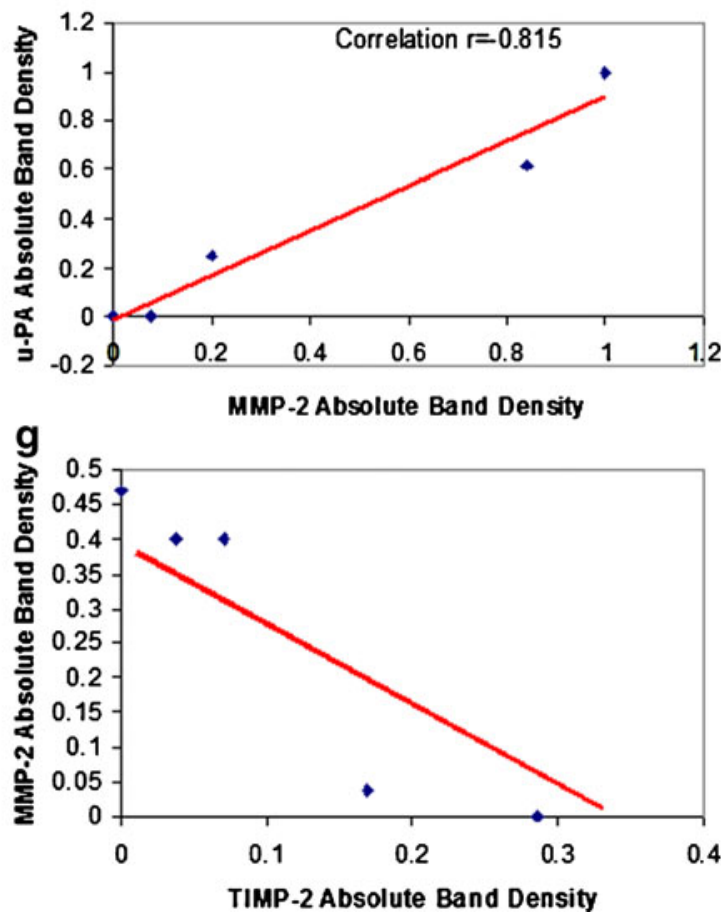

TIMPs secretion (d). Correlation between: PC-3 u-PA and MMP-2 expression (e), PC-3 TIMP-2 and u-PA expression (f), PC-3 MMP-2 and TIMP-2 expression (g) 
NM inhibited MMPs in a dose-dependent manner in all cancer cells tested. Representative of a cancer cell line expressing both MMP-2 and MMP-9, prostate cancer cell line PC-3 is shown in Fig. 7. Zymography showed bands representing MMP-2 and MMP-9 in normal and PMAtreated PC-3 cells. NM inhibited secretion of both MMPs in a dose-dependent manner.

Densitometry analysis of normal PC-3 secretion showed $100 \%$ inhibition of MMP-2 and MMP-9 at $500 \mu \mathrm{g} / \mathrm{ml} \mathrm{NM}$, with linear trend of $R^{2}=0.831$ (MMP-2) and $R^{2}=0.715$ (MMP-9). For PMA-induced PC-3 cells, relative activity of MMP-2 revealed $100 \%$ inhibition at $250 \mu \mathrm{g} / \mathrm{ml} \mathrm{NM}$, with linear trend of $R^{2}=0.750$. MMP-9 relative density showed $100 \%$ inhibition at $500 \mu \mathrm{g} / \mathrm{ml} \mathrm{NM}$, with $R^{2}=0.883$ [38].

In vivo results also demonstrated modulation of MMP-9 secretion with NM treatment. Tumor tissue from xenograft studies demonstrated reduction of MMP-9 secretion when the mice were fed a diet supplemented with NM $0.5 \%$. For example, xenografts of human fibrosarcoma HT-1080 cells in male athymic mice showed reduction of MMP-9 secretion with NM supplementation, as shown in Fig. 8. Standard immunohistochemical staining procedures using polyclonal rabbit anti-human antibodies were used for MMP-9.

\subsubsection{Nutrient synergy increases TIMPS and decreases $u$-PA activities}

Studies of several cancer cell lines demonstrated downregulated activity of $\mathrm{u}-\mathrm{PA}$ and up-regulated activity of TIMPs. Cells were treated with NM at 0, 10, 50, 100, 500, and $1,000 \mu \mathrm{g} / \mathrm{ml}$. U-PA activity was analyzed by fibrin zymography on $10 \%$ SDS-PAGE gels containing fibrinogen

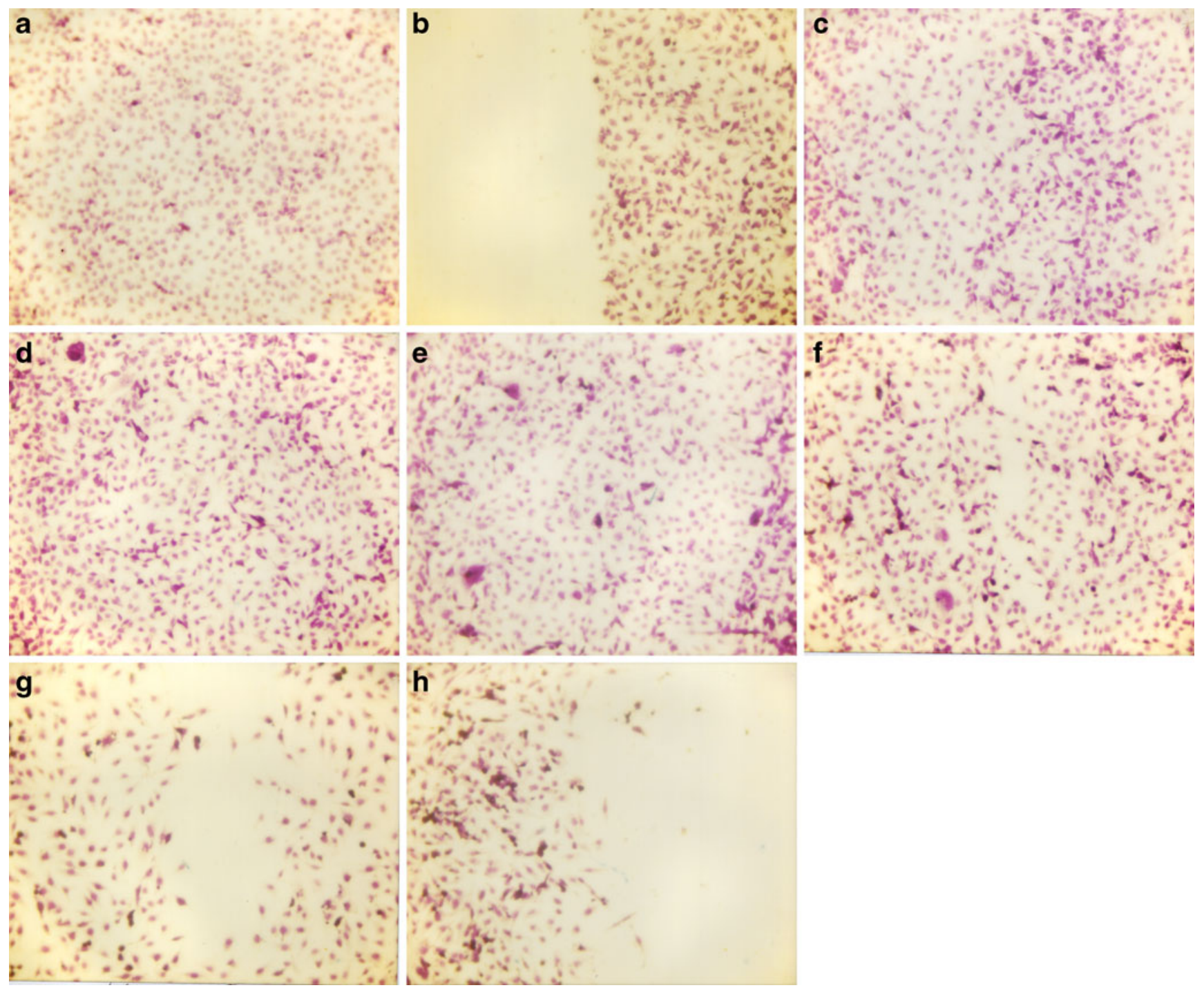

Fig. 10 Effect of NM on migration of T-24 cells: scratch test. a Control pre-scratch, b control scratch, c control $24 \mathrm{~h}, \mathbf{d ~ N M ~} 50 \mu \mathrm{g} / \mathrm{ml} 24 \mathrm{~h}$, e NM $100 \mu \mathrm{g} / \mathrm{ml} 24$ h, f NM $250 \mu \mathrm{g} / \mathrm{ml} 24$ h, g NM $500 \mu \mathrm{g} / \mathrm{ml} 24$ h, h NM 1,000 $\mu \mathrm{g} / \mathrm{ml} 24 \mathrm{~h}$ 
$(5.5 \mathrm{mg} / \mathrm{mL})$ and plasminogen $(50 \mu \mathrm{g} / \mathrm{mL})$. After electrophoresis, the gels were washed twice with $2.5 \%$ Triton X100 for $30 \mathrm{~min}$. The gels were then incubated overnight at $37^{\circ} \mathrm{C}$ with $0.1 \%$ glycine buffer $\mathrm{pH} 7.5$ and then stained with $0.5 \%$ Coomassie Brilliant Blue R250 and destained. Electrophoresis of u-PA was conducted for comparison. Fibrin zymograms were scanned using CanoScan 9950F Canon Scanner. TIMPS were analyzed by reverse zymography on $15 \%$ SDS gels containing serum-free conditioned medium from cells. After electrophoresis the gels were washed twice with $2.5 \%$ Triton-X for $30 \mathrm{~min}$ at room temperature to remove SDS. The gels were then incubated at $37^{\circ}$ overnight in $50 \mathrm{mM}$ Tris- $\mathrm{HCl}$ and $10 \mathrm{mM} \mathrm{Ca} \mathrm{Cl}_{2}$ at $\mathrm{pH} 7.6$ and stained with $0.5 \%$ Coomassie Blue R25, destained and scanned.

The results obtained with prostate PC-3 cell line, presented here, are representative of findings for other cell lines [38]. U-PA activity was detected in PC-3 prostate cancer cell line, showing two bands corresponding to molecular weights 35 and $33 \mathrm{kD}$. NM inhibited their expression in a dose response manner, with significant reduction in u-PA activity at $250 \mu \mathrm{g} / \mathrm{ml} \mathrm{NM}$ (Fig. 9a-b).

Activity of TIMPs was upregulated in PC-3 in a dosedependent manner (Fig. 9c-d). Minimum activity was expressed at $50 \mu \mathrm{g} / \mathrm{ml}$ and maximum at $1,000 \mu \mathrm{g} / \mathrm{ml}$. Analysis revealed a positive correlation $(r=0.977)$ between PC-3 u-PA and MMP expression (Fig. 9e), a negative correlation $(r=-0.939)$ between expression of u-PA and TIMP-2 (Fig. 9f) and a negative correlation $(r=-0.781)$ between MMPs and TIMP-2 (Fig. 9g).

\subsubsection{Nutrient synergy has inhibitory effect on cancer cell migration}

To study cell migration, a 2-mm wide single uninterrupted scratch was made from top to bottom of culture plates of cancer cells grown to confluence. Culture plates were washed with phosphate-buffered saline (PBS) and incubated with NM in medium and tested at $0,10,50,100,500$, and $1,000 \mu \mathrm{g} / \mathrm{ml}$ in triplicate at each dose for $24 \mathrm{~h}$. Cells were washed with PBS, fixed and stained with H\&E and photomicrographs were taken. A representative example is shown with bladder cancer cells [39]. NM reduced bladder cancer cell line T-24 cell migration in a dose-dependent fashion, with total inhibition at $1,000 \mu \mathrm{g} / \mathrm{ml}$ (Fig. 10).

\subsubsection{Nutrient synergy inhibits Matrigel invasion by cancer cells}

Invasion studies were conducted on many cancer cell lines using Matrigel (Becton Dickinson) inserts in 24-well plates. Table 3 summarizes the concentration of NM required to completely block Matrigel invasion in a variety of cancer
Table 3 Effect of NM on cancer cell Matrigel invasion

\begin{tabular}{ll}
\hline Cancer cell line & $\begin{array}{l}\text { NM concentration to achieve } \\
100 \% \text { block of ECM } \\
\text { invasion }(\mu \mathrm{g} / \mathrm{mL})\end{array}$ \\
\hline $\begin{array}{ll}\text { Breast (MBA-MB-231) } \\
\text { Breast (MCF-7 estrogen sensitive) }\end{array}$ & 100 \\
+estradiol & 100 \\
Osteosarcoma (MNNG/U2OS) & 100 \\
Cervical cancer HeLa & 500 \\
Lung carcinoma (A-549) & 500 \\
Pancreas (MIA PACA-2) & 500 \\
Prostate (LNCaP) & 500 \\
Colon (HCT 116) & 500 \\
Rhabdomyosarcoma & 500 \\
Prostate (DU-145) & 500 \\
Thyroid SW 579 & 500 \\
Hepatocellular carcinoma SK-Hep-1 & 1,000 \\
Bladder Cancer (T-24) & 1,000 \\
Fibrosarcoma HT1080 & 1,000 \\
Cervical Cancer (DoTc2451) & 1,000 \\
Ovarian SK-OV-3 & 1,000 \\
Prostate PC-3 & 1,000 \\
Renal carcinoma 786-0 & 1,000 \\
Synovial carcinoma & 1,000 \\
Melanoma A2058 & 1,000 \\
Glioma A-172 & 1,000 \\
Liposarcoma SW-872 & 1,000 \\
&
\end{tabular}

cell lines. Suspended in medium, cancer cells were supplemented with nutrients, as specified in the design of the experiments and seeded on the insert in the well. Thus, both the medium on the insert and in the well contained the same supplements. The plates with the inserts were then incubated in a culture incubator equilibrated with $95 \%$ air and $5 \% \mathrm{CO} 2$ for $24 \mathrm{~h}$. After incubation, the media from the wells were withdrawn. The cells on the upper surface of the inserts were gently scrubbed away with cotton swabs. The cells that had penetrated the Matrigel membrane and migrated onto the lower surface of the Matrigel were stained with hematoxylin and eosin and visually counted under the microscope.

A representative example is the effect of NM on bladder cancer cell line T-24. NM significantly inhibited T-24 cell invasion through Matrigel in a dose-dependent manner, with $60 \%(p=0.0006)$ at $50 \mu \mathrm{g} / \mathrm{ml}, 81 \%(p=0.0002)$ at $100 \mu \mathrm{g} / \mathrm{ml}, 95 \%(p=0.0001)$ inhibition at $500 \mu \mathrm{g} / \mathrm{ml}$ and $100 \%(p=0.0001)$ at $1,000 \mu \mathrm{g} / \mathrm{ml} \mathrm{NM}$ compared to control [39]. There was significant negative correlation between NM concentration and number of T-24 cells that invaded/ migrated through Matrigel: $r=-0.6955, p=0.001$ (Fig. 11). 


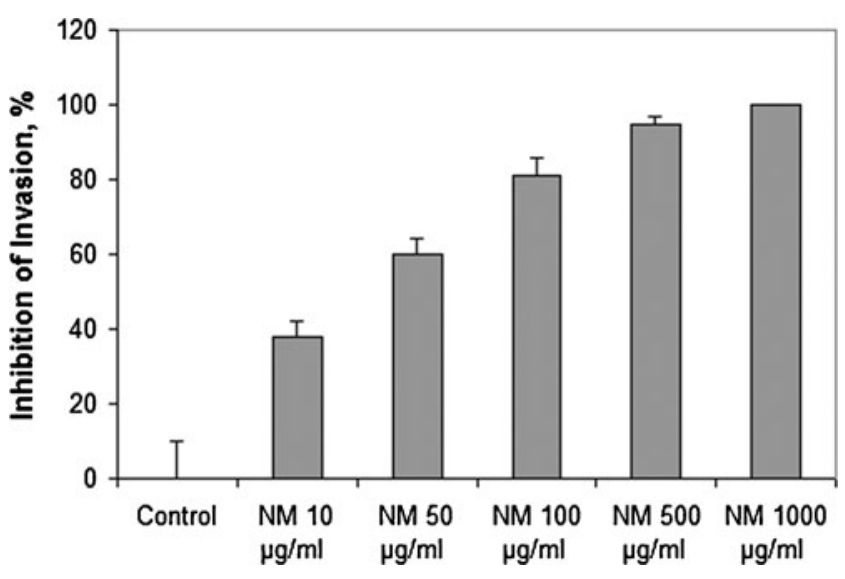

Fig. 11 Effect of NM on Matrigel invasion of T-24 cells

2.3 Nutrient synergy inhibits cancer cell growth and induces apoptosis

ECM degradation is a prerequisite for cancer metastasis, but also it is essential to tumor growth and expansion and angiogenesis. Therefore, we investigated the effects of nutrient synergy on these important aspects of malignancy.

\subsubsection{Inhibition of tumor growth (xenografts)}

NM has been shown to modulate xenograft tumor growth in a variety of cancer cell lines. Table 4 presents results we obtained with some of these cell lines. For example, male athymic mice 6 weeks of age $(n=12)$ were inoculated subcutaneously with $3 \times 10^{6}$ A2058 cells in $0.2 \mathrm{ml} \mathrm{PBS}$ and $0.1 \mathrm{ml}$ Matrigel. After injection, the mice were randomly divided into two groups; group A mice were fed regular Purina mouse chow and group B the regular diet supplemented with $0.5 \% \mathrm{NM}(w / w)$. After 4 weeks, the mice were sacrificed and their tumors were excised and processed for histology. Dimensions (length and width) of tumors were measured using a digital caliper, and the tumor burden was calculated using the following formula: $0.5 \times$ length $\times$ width. Mean weight of mice at initiation of study and termination of study did not differ significantly between the groups. The melanoma xenograft study showed that NM supplementation inhibited tumor weight by $57 \%(p<0.0001)$ and tumor burden by $31 \%$ over control diet.

\subsubsection{Decreased cancer cell proliferation in the presence of nutrient synergy}

We evaluated the effect of various concentrations of NM on the viability of various cancer cell lines utilizing the [3(4,5-dimethylthiazol-2-yl) 2,5-diphenyl tetrazolium bromide] MTT assay, a colorimetric assay based on the ability of viable cells to reduce a soluble yellow tetrazolium salt
Table 4 Effect of NM diet on tumor weight and burden in xenograft studies

\begin{tabular}{lll}
\hline Cancer cell line & $\begin{array}{l}\text { Reduction of tumor } \\
\text { weight by NM diet } \\
\text { over control diet }\end{array}$ & $\begin{array}{l}\text { Reduction of tumor } \\
\text { burden by NM diet } \\
\text { over control diet }\end{array}$ \\
\hline SK-Hep-1 & $42 \%(p=0.09)$ & $36 \%(p=0.005)$ \\
Colon HCT-116 & $63 \%(p=0.0002)$ & $46 \%(p=0.0005)$ \\
Prostate PC-3 & $47 \%(P<0.0001)$ & $53 \%(p=0.0002)$ \\
Lung A-549 & $44 \%(p=0.001)$ & $47 \%(p<0.0001)$ \\
Melanoma A2058 & $57 \%(p<0.0001)$ & $31 \%$ \\
\hline
\end{tabular}

MTT to a blue formazan crystal by mitochondrial succinate dehydrogenase activity of viable cells. This test is a good index of mitochondrial activity and thus of cell viability. Inhibition of cell proliferation was confirmed in a variety of cancer cell lines, as shown in Table 5.

\subsubsection{Induction of cancer cell apoptosis by nutrient synergy}

We investigated pro-apoptotic effects of nutrient synergy in various types of tumors using the following tests: live green caspases, DNA fragmentation, expression of pro-apoptotic genes, and cell cycle. An example of live green caspace test is described below. To study the effect of NM on apoptosis of cancer cells, cells were grown to confluence, challenged

Table 5 Effect of NM on cancer cell proliferation

\begin{tabular}{ll}
\hline Cancer cell line & $\begin{array}{l}\text { Percent Inhibition of } \\
\text { cell growth at NM } \\
1,000 \mu \mathrm{g} / \mathrm{mL}\end{array}$ \\
\hline Breast (MBA-MB-231) & $50 \%$ \\
Breast (MCF-7 estrogen sensitive)+estradiol & $25 \%$ \\
Osteosarcoma (MNNG) & $10 \%$ \\
Cervical cancer HeLa & $37 \%$ \\
Lung carcinoma (A-549) & $20 \%$ \\
Pancreas (MIA PACA-2) & $38 \%$ \\
Prostate (LNCaP) & $80 \%$ \\
Osteosarcoma (U2OS) & $60 \%$ \\
Rhabdomyosarcoma & $20 \%$ \\
Prostate (DU-145) & $47 \%$ \\
Hepatocellular carcinoma SK-Hep-1 & $33 \%$ \\
Fibrosarcoma HT1080 & $37 \%$ \\
Cervical Cancer (DoTc2451) & $45 \%$ \\
Prostate PC-3 & $40 \%$ \\
Synovial carcinoma & $28 \%$ \\
Melanoma A2058 & $64 \%$ \\
Glioma A-172 & $50 \%$ \\
Liposarcoma SW-872 & $61 \%$ \\
\hline
\end{tabular}



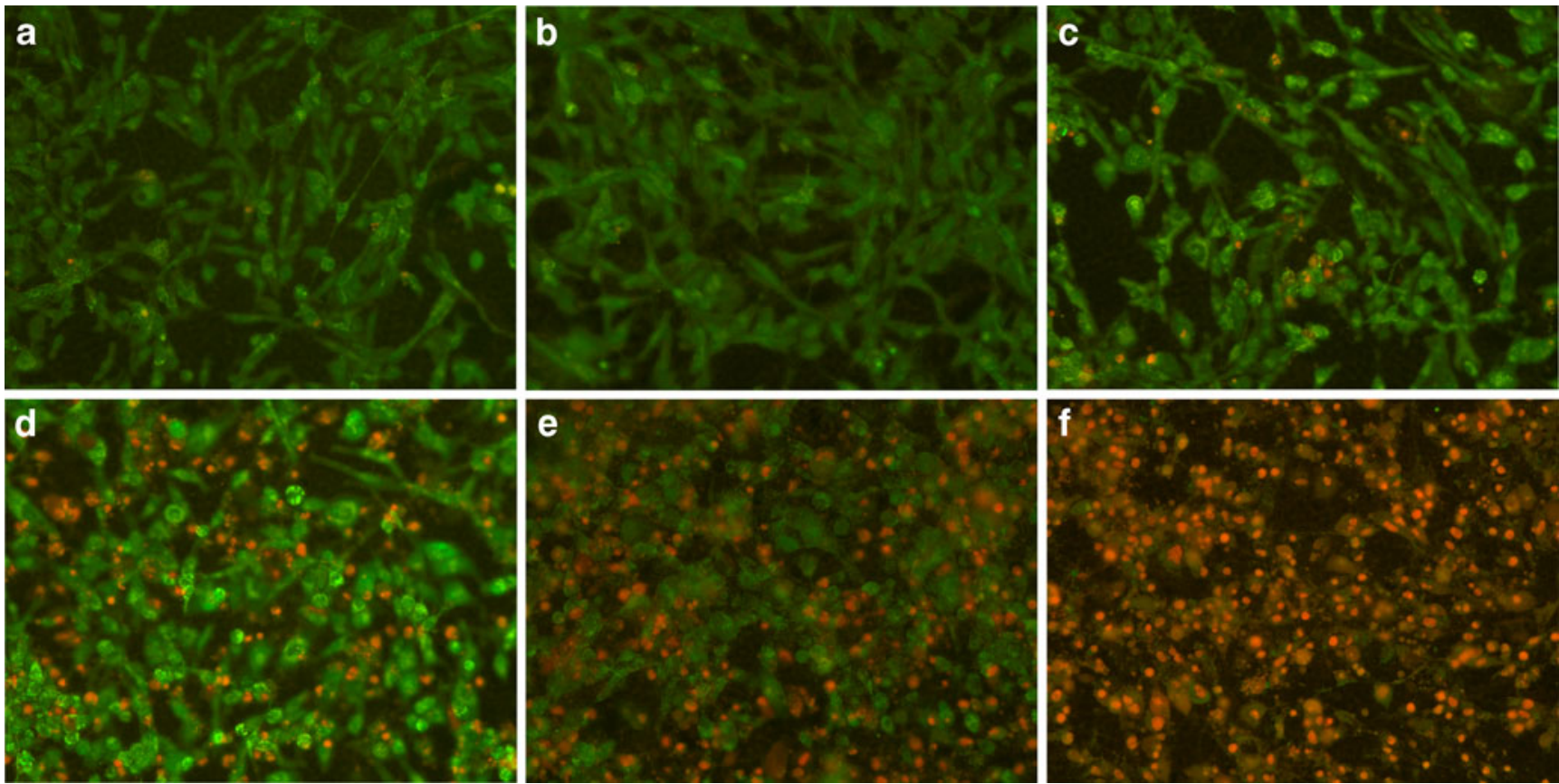

Fig. 12 Effect of NM on apoptosis of rhabdomyosarcoma cells: live-green caspases a control, b NM $50 \mu \mathrm{g} / \mathrm{ml}, \mathbf{c} \mathrm{NM} 100 \mu \mathrm{g} / \mathrm{ml}$, d NM $250 \mu \mathrm{g} /$ $\mathrm{ml}$, e NM $500 \mu \mathrm{g} / \mathrm{ml}, \mathbf{f} \mathrm{NM} 1,000 \mu \mathrm{g} / \mathrm{ml}$

with NM dissolved in media at $0,50,100,250,500$, and $1,000 \mu \mathrm{g} / \mathrm{ml}$ and incubated for $24 \mathrm{~h}$. The cell culture was washed with PBS and treated with the caspase reagent as specified in the manufacturer's protocol (Molecular Probes Image-ITTM Live Green Poly Caspases Detection Kit 135104, Invitrogen). The cells were photographed under a fluorescence microscope and counted. Green-colored cells represent viable cells, while yellow orange represents early apoptosis and red, late apoptosis. Dose-dependent induction of apoptosis in a variety of cancer cell lines was confirmed with NM challenge. The effect of NM on apoptosis in rhabdosarcoma cells is shown in Fig. 12 [40]. At $100 \mu \mathrm{g} / \mathrm{ml}$ $\mathrm{NM}, 95 \%$ of cells were viable and $5 \%$ in apoptosis, at $250 \mu \mathrm{g} / \mathrm{ml} \mathrm{NM}, 46 \%$ were viable, $13 \%$ in early apoptosis and $41 \%$ in late apoptosis, at $500 \mu \mathrm{g} / \mathrm{ml} \mathrm{NM}, 28 \%$ of cells

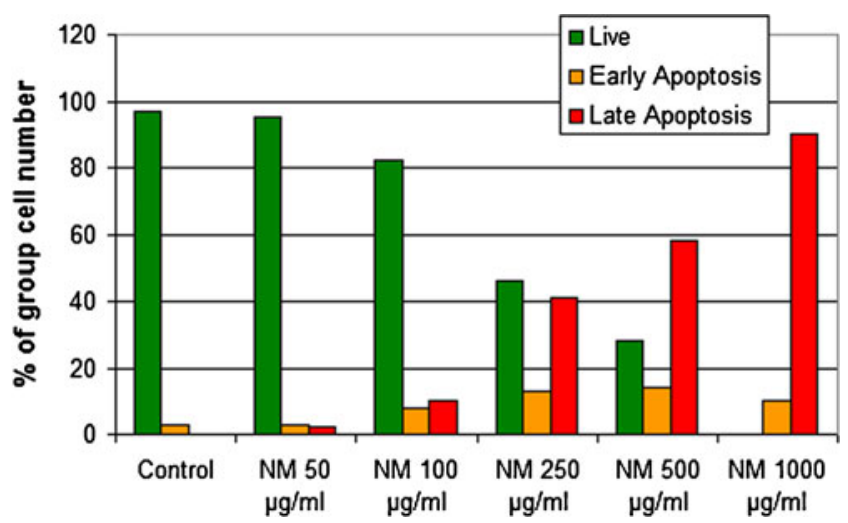

Fig. 13 Quantitative analysis of live, early and late apoptotic cells were viable, $14 \%$ in early apoptosis, and $58 \%$ in late apoptosis. Virtually all cells exposed to $1,000 \mu \mathrm{g} / \mathrm{ml} \mathrm{NM}$ were apoptotic. Quantitative analysis of live, early and late apoptotic cells is shown in Fig. 13. Studies by Harakeh et al. [41] have shown that NM induces apoptosis of adult Tcell leukemia cells and acute leukemia cells by the modulation of p53, p21, Bcl-2 and Bax protein levels.

\subsubsection{Nutrient synergy modulates cancer cell cycle}

We also studied the effect of NM on cell cycle in cancer cells since disregulation of the cell cycle components may lead to tumor formation. As an example, melanoma cells A2058 were cultured in a 6 -well plate at a concentration of $0.5 \times 106$ cells per well. The cells were incubated with NM

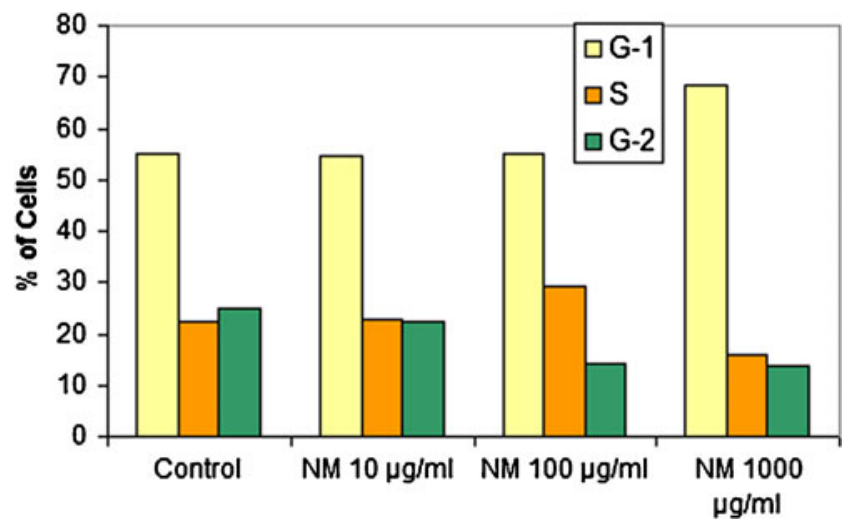

Fig. 14 Effect of NM on cell cycle of melanoma A-2058 cells 
at $0,10,100$, and $1,000 \mu \mathrm{g} / \mathrm{ml}$ for $24 \mathrm{~h}$ and harvested. The cells were washed once with PBS and fixed in $70 \%$ ethanol. Cell pellets were suspended in $2 \mu \mathrm{L}$ of $10 \mu \mathrm{g} / \mathrm{ml}$ RNase containing $0.5 \%$ Triton and the same volume of $20 \mu \mathrm{g} / \mathrm{ml}$ propidium iodide, followed by incubation in the dark at room temperature for $30 \mathrm{~min}$. Cell fluorescence was measured in the Coulter EPIC Flow Cytometer. Melanoma A-2058 cells exposed to NM showed dose-dependent increase of \% of cells in the G-1 phase and decrease in G-2 and G-3 phases, indicating decrease in cells ready to undergo mitosis. See Fig. 14. Earlier studies also indicated cell cycle arrest of adult T-cell leukemia and acute leukemia cells by NM [41].

2.4 Nutrient synergy modulates Cox-2 expression in cancer cells

Inflammatory proteins such as Cox-2 contribute to carcinogenesis of human tumors and have been found to be elevated in cancer patients. Cox-2 proteins were determined by Western blot analysis using polyclonal antibodies against Cox-2. Briefly, the cell were lysed for $30 \mathrm{~min}$ in ice cold radioimmunoprecipitation buffer $(50 \mathrm{mM}$ Tris- $\mathrm{HCl}, \mathrm{pH} 7.5$, $10 \%$ Triton X-100, 1.0\% Na-deoxycholate, $150 \mathrm{mM} \mathrm{NaCl}$, $2 \mathrm{mM}$ EDTA) with $1 \mathrm{mM}$ activated orthovandate, and $1 \times$ Complete Mini Protease Inhibitor Cocktail tablet. Clarified cell lysates were denatured and equal proteins loaded and fractionated by SDS-polyacrylamide gel electrophoresis. After electrophoresis, the proteins were transferred to nitrocellulose membrane. The membranes were then incubated with the respective antibodies and developed by the enhanced chemiluminescence system. We found Cox-2 expression by bladder cancer T-24 cells exposed to NM to be reduced in a dose-dependent fashion [39]. A study of the effect of another micronutrient mixture including ascorbic acid, quercetin, naringenin, hesperitin, tea catechins, lysine, proline, arginine, and $\mathrm{N}$-acetyl cysteine on inflammatory gene expression found that this mixture inhibited Cox-2 enzymatic activity and down regulated pro-inflammatory cytokine protein expression at the transcription level complementing a blockade in $\mathrm{NFk} \beta$ activation [42].

\section{Safety of NM}

In contrast to the toxic side effects of current treatments, the micronutrient mixture has been shown to be a safe therapeutic agent. In a previous in vivo study addressing safety issues, we found that gavaging adult female ODS rats (weighing 250-300 g) with the nutrient mixture (at 30, 90 , or $150 \mathrm{mg}$ per day for 7 days), had neither adverse effects on vital organs (heart, liver, and kidney), nor on the associated functional serum enzymes, indicating that this mixture is safe to use even at these high doses, which far exceed the normal equivalent dosage of the nutrient [43].

\section{Conclusions}

In conclusion, the synergistic micronutrient mixture has been shown to be effective against multiple targets in cancer development and progression. These results indicate that this non-toxic comprehensive approach should be considered in cancer therapy as a safe and economical approach.

Open Access This article is distributed under the terms of the Creative Commons Attribution Noncommercial License which permits any noncommercial use, distribution, and reproduction in any medium, provided the original author(s) and source are credited.

\section{References}

1. Cancer trends progress report-2009/2010 update, NCI. Accessed from http://progressreport.cancer.gov/doc_detail.asp?pid=1\&$\mathrm{did}=2007 \&$ chid= $76 \&$ coid $=729 \&$ mid $=$. Accessed on April 26, 2010.

2. Morgan, G., Ward, R., \& Barton, M. (2004). The contribution of cytotoxic chemotherapy to 5-year survival in adult malignancies. Clinical Oncology, 16(8), 549-560.

3. Aldercreutz, H. (1990). Western diet and Western disease: some hormonal and biochemical mechanisms and associations. Scandinavian Journal of Clinical and Laboratory Investigation Supplementation, 201, 3-23.

4. Miller, A. B. (1990). Diet and Cancer: A review. Acta Oncológica, 29(1), 87-95.

5. Rath, M., \& Pauling, L. (1992). Plasmin-induced proteolysis and the role of apoprotein(a), lysine and synthetic analogs. Orthomolecular Medicine, 7, 17-23.

6. Almholt, K., Lundt, L. R., Rygaard, J., Nielsen, B. S., Danø, K., Rømer, J., et al. (2005). Reduced metastasis of transgenic mammary cancer in urokinse-deficient mice. International Journal of Cancer, 113(4), 525-532.

7. Stetler-Stevenson, W. G. (2001). The role of matrix metalloproteinases in tumor invasion, metastasis and angiogenesis. Surgical Oncology Clinics of North America, 10, 383-392.

8. Duffy, M. J. (1992). The role of proteolytic enzymes in cancer invasion and metastasis. Clinical \& Experimental Metastasis, 10, 145-155.

9. Chambers, A. F., \& Matrisian, L. M. (1997). Changing views on the role of matrix metalloprotenases in metastasis. Journal of the National Cancer Institute, 89(17), 1260-1270.

10. Kleiner, D. L., \& Stetler-Stevenson, W. G. (1999). Matrix metalloproteinases and metastasis. Cancer Chemotherapy and Pharmacology, 43(suppl), 42s-51s.

11. Liotta, L. A., Tryggvason, K., Garbisa, A., Hart, I., Foltz, C. M., \& Shafie, S. (1980). Metastatic potential correlates with enzymatic degradation of basement membrane collagen. Nature, 284, 67-68.

12. Stetler-Stevenson, W. G., Hewitt, R., \& Corcoran, M. (1996). Matrix metalloproteinases and tumor invasion from correlation and causality to the clinic. Seminars in Cancer Biology, 7, 147-154.

13. Ivanov, V., Ivanova, S., Roomi, M. W., Kalinovsky, T., Niedzwiecki, A., \& Rath, M. (2007). Naturally-produced extracellular matrix inhibits growth rate and invasiveness of human osteosarcoma cancer cells. Medical Oncology, 24(2), 209-217. 
14. Roomi, M. W., Ivanov, V., Kalinovsky, T., Niedzwiecki, A., \& Rath, M. (2006). Inhibition of pulmonary metastasis of melanoma $\mathrm{B} 16 \mathrm{FO}$ cells in C57BL/6 mice by a nutrient mixture consisting of ascorbic acid, lysine, proline, arginine, and green tea extract. Experimental Lung Research, 32(10), 517-530.

15. Roomi, M. W., Roomi, N., Ivanov, V., Kalinovsky, T., Niedzwiecki, A., \& Rath, M. (2005). Inhibitory effect of a mixture containing ascorbic acid, lysine, proline, and green tea extract on critical parameters in angiogenesis. Oncology Reports, 14(4), 807-815.

16. Sun, Z., Chen, Y. H., Wang, P., Zhang, J., Gurewich, V., Zhang, P., et al. (2002). The blockage of high-affinity lysine binding sites of plasminogen by EACA significantly inhibits prourokinase-induced plasminogen activation. Biochem Biophys Acta, 1596, 182-192.

17. Kemberling, J. K., Hampton, J. A., Keck, R. W., Gomez, M. A., \& Selman, S. H. (2003). Inhibition of bladder tumor growth by the green tea derivative epigallocatechin-3-gallate. Journal d'Urologie, 170(3), 773-776.

18. Sato, D., \& Matsushima, M. (2003). Preventive effects of urinary bladder tumors induced by N- butyl-N-(4-hydroxybutyl)-nitrosamine in rat by green tea leaves. International Journal of Urology, 10(3), 160-166.

19. Valcic, S., Timmermann, B. N., Alberts, D. S., Wachter, G. A., Krutzsch, M., Wymer, J., et al. (1996). Inhibitory effect of six green tea catechins and caffeine on the growth of four selected human tumor cell lines. Anti-Cancer Drugs, 7, 461-468.

20. Mukhtar, H., \& Ahmed, N. (2000). Tea polyphenols: Prevention of cancer and optimizing health. The American Journal of Clinical Nutrition, 71, 1698s-1702s.

21. Yang, G. Y., Liao, J., Kim, K., Yurtow, E. J., \& Yang, C. S. (1998). Inhibition of growth and induction of apoptosis in human cancer cell lines by tea polyphenols. Carcinogenesis, 19, 611-616.

22. Taniguchi, S., Fujiki, H., Kobayashi, H., Go, H., Miyado, K., Sadano, H., et al. (1992). Effect of (-) epigallocatechin gallate, the main constituent of green tea, on lung metastasis with mouse B16 melanoma cell lines. Cancer Letters, 65, 51-54.

23. Hara, Y. (2001). Green tea: Health Benefits and Applications. New York: Marcel Dekker.

24. Kawakami, S., Kageyama, Y., Fujii, Y., Kihara, K., \& Oshima, H. (2001). Inhibitory effects of N- acetyl cysteine on invasion and MMP 9 production of T24 human bladder cancer cells. Anticancer Research, 21, 213-219.

25. Morini, M., Cai, T., Aluigi, M. G., Noonan, D. M., Masiello, L., De Floro, S., et al. (1999). The role of the thiol N-acetyl cysteine in the prevention of tumor invasion and angiogenesis. The International Journal of Biological Markers, 14, 268-271.

26. Yoon, S. O., Kim, M. M., \& Chung, A. S. (2001). Inhibitory effects of selenite on invasion of HT 1080 tumor cells. The Journal of Biological Chemistry, 276, 20085-20092.

27. Maramag, C., Menon, M., Balaji, K. C., Reddy, P. G., \& Laxmanan, S. (1997). Effect of vitamin C on prostate cancer cells in vitro: effect on cell number, viability and DNA synthesis. The Prostate, 32, 188-195.

28. Koh, W. S., Lee, S. J., Lee, H., Park, C., Park, M. H., Kim, W. S., et al. (1998). Differential effects and transport kinetics of ascorbate derivatives in leukemic cell lines. Anticancer Research, 8, 2487-2493.

29. Chen, Q., Espey, M. G., Krishna, M. C., Mitchell, J. B., Corpe, C. P., Buettner, G. R., et al. (2005). Pharmacologic ascorbic acid concentrations selectively kill cancer cells: Action as a pro-drug to deliver hydrogen peroxide to tissues. PNAS, 102 (38), 13604-13609.

30. Nunez, C., Ortiz de Apodaca, Y., \& Ruiz, A. (1995). Ascorbic acid in the plasma and blood cells of women with breast cancer.
The effect of consumption of food with an elevated content of this vitamin. Nutrición Hospitalaria, 10, 68-372.

31. Kurbacher, C. M., Wagner, U., Kolster, B., Andreotti, P. E., Krebs, D., \& Bruckner, H. W. (1996). Ascorbic acid (vitamin C) improves the antineoplastic activity doxorubicin, cisplatin and paclitaxel in human breast carcinoma cells in vitro. Cancer Letters, 103(2), 183-189.

32. Cooke, J. P., \& Dzau, V. J. (1997). Nitric oxide synthase: Role in the genesis of vascular disease. Annual Review of Medicine, 48, 489-509.

33. Kale, A., Gawande, S., Kotwal, S., Netke, S., Roomi, M. W., Ivanov, V., et al. (2010). A combination of green tea extract, specific nutrient mixture and quercetin: An effective intervention treatment for the regression of N-methyl-N-nitrosourea (MNU)-induced mammary tumors in Wistar rats. Onc Letters, $1,313-317$.

34. Roomi, M. W., Roomi, N. W., Ivanov, V., Kalinovsky, T., Niedzwiecki, A., \& Rath, M. (2005). Modulation of N-methyl$\mathrm{N}$-nitrosourea induced mammry tumors in Sprague-Dawley rats by combination of lysine, proline, arginine, ascorbic acid and green tea extract. Breast Cancer Research, 7, R291-R295.

35. Roomi, M. W., Roomi, N. W., Ivanov, V., Kalinovsky, T., Niedzwiecki, A., \& Rath, M. (2006). Inhibition of pulmonary metastasis of melanoma B16FO cells in C57BL/6 mice by a nutrient mixture consisting of ascorbic acid, lysine, proline, arginine, and green tea extract. Experimental Lung Research, 32, 517-530.

36. Roomi, M. W., Kalinovsky, T., Roomi, N. W., Monterrey, J., Rath, M., \& Niedzwiecki, A. (2009). A nutrient mixture suppresses hepatic metastasis in athymic nude mice injected with murine B16FO melanoma cells. Biofactors, 33, 181-189.

37. Roomi, M. W., Kalinovsky, T., Roomi, N. W., Monterrey, J., Rath, M., \& Niedzwiecki, A. (2008). Suppression of growth and hepatic metastasis of murine B16FO melanoma cells by a novel nutrient mixture. Oncology Report, 20, 809-817.

38. Roomi, M. W., Roomi, N. W., Rath, M., Niedzwiecki, A. (2009). Downregulation of urokinase plasminogen activiator (u-PA), matrix metalloproteinases (MMPs) and upregulation of their inhibitors (TIMPs) by a novel nutrient mixture in human prostate cancer cell lines PC-3 and Du-145. Proceedings of the $100^{\text {th }}$ Annual Meeting of the AACR 2009, abstract 2217, p. 270.

39. Roomi, M. W., Kalinovsky, T., Niedzwiecki, A., \& Rath, M. (2009). Pleiotropic effects of a micronutrient mixture on critical parameters of bladder cancer. In W. E. Nilsson (Ed.), Bladder cancer etymology, diagnosis and treatments. New York: Nova Science Publishers Inc.

40. Roomi, M. W., Ivanov, V., Kalinovsky, T., Niedzwiecki, A., \& Rath, M. (2007). In vitro anticarcinogenic effect of a nutrient mixture on human rhabdomyosarcoma cells. Gene Therapy and Molecular Biology, 11, 133-142.

41. Harakeh, S., Diab-Assaf, M., Niedzwiecki, A., Khalife, J. C., Abu-El-Ardat, K., \& Rath, M. (2006). Apoptosis induction by Epican Forte in HTLV-1 positive and negative malignant T-cells. Leukemia Research, 30(7), 869-881.

42. Ivanov, V., Cha, J., Ivanova, S., Kalinovsky, T., Roomi, M. W., Rath, M., et al. (2008). Essential nutrients suppress inflammation by modulating key inflammatory gene expression. International Journal of Molecular Medicine, 22(6), 731-742.

43. Roomi, M. W., Ivanov, V., Netke, S. P., Niedzwiecki, A., \& Rath, M. (2003). Serum markers of the liver, heart, and kidney and lipid profile and histopathology in ODS rats treated with nutrient synergy. Journal of the American College of Nutrition, 22, 477. Abstract 86. 